\title{
Prediction, prevention and personalisation of medication for the prenatal period: genetic prenatal tests for both rare and common diseases
}

\author{
Munis Dundar • Asli Subasioglu Uzak • \\ Murat Erdogan - Yagut Akbarova
}

Received: 19 February 2011 / Accepted: 24 March 2011 /Published online: 6 May 2011

(C) European Association for Predictive, Preventive and Personalised Medicine 2011

\begin{abstract}
Genetic testing usually helps physicians to determine possible genetic diseases in unborn babies, genetic disorders of patients and the carriers who might pass the mutant gene on to their children. They are performed on blood, tissues or other body fluids. In recent years, the screening tests and diagnostic tests have improved quickly and, as a result, the risks of pregnancy can be determined more commonly and physicians can diagnose several genetic disorders in the prenatal period. Detecting the abnormalities in utero enables correct management of the pregnancy, prenatal and postnatal medical care, and it is also important for making well informed decisions about continuing or terminating a pregnancy. Besides the improvements of conventional invasive diagnostic tests, the discovery of circulating cell-free foetal nucleic acids in maternal plasma has developed a new point of view for non-invasive prenatal diagnosis recently.
\end{abstract}

Keywords Prenatal diagnosis - Prenatal screening tests . Common genetic disorders - Genetic counselling · Prediction · Prevention and personalised medicine - PPPM early in life

\section{Introduction}

Genetic testing usually helps physicians to determine possible genetic diseases in both the prenatal and postnatal

M. Dundar $(\bowtie) \cdot$ A. S. Uzak $\cdot$ M. Erdogan $\cdot$ Y. Akbarova

Erciyes University,

Kayseri, Turkey

e-mail: dundar@erciyes.edu.tr periods. The main purposes are: to find out the genetic disorders of the patients, the carriers who might pass the mutant gene on to their children, the genetic diseases in adults before they cause symptoms and to confirm the clinical diagnosis in a patient who has symptoms. Sometimes a disease can be prevented or treated if a mutant gene is detected. Sometimes there is no treatment, but the test results might help a person to make life decisions, such as giving up smoking and keeping in training. Genetic tests can be divided into two main groups: prenatal and postnatal. Substantially, there is not much difference between them. After obtaining the material that will be used in genetic diagnosis, the postnatal and prenatal procedures progresses are same. Genetic diseases can be divided into four main groups: single-gene disorders, chromosomal disorders, multifactorial disorders and mitochondrial disorders.

1. Single-gene disorders, also called Mendelian or monogenic, are a type that are caused by changes or mutations in the DNA sequence of one gene. Examples include cystic fibrosis, sickle cell anemia, Marfan syndrome and Huntington's disease.

2. Chromosomal disorders include numerical and structural anomalies. Chromosomes are distinct structures made up of DNA and protein which carry genetic material. Abnormalities such as missing or extra copies or gross breaks and rejoinings (translocations) effect the genome and so can result in diseases.

3. Multifactorial disorders, also called as complex or polygenic, are a type that are caused by a combination of environmental factors and mutations in multiple genes. Examples include Alzheimer's disease, diabetes mellitus and cancer. 
4. Mitochondrial disorders are caused by mutations in the nonchromosomal DNA of mitochondria. The disorders that related with this type are rare and examples include Kearns-Sayre syndrome, myoclonus epilepsy with ragged red fibres, and mitochondrial encephalomyopathy with lactic acidosis and stroke-like episodes (MELAS).

\section{What is a syndrome?}

A syndrome is a group of multiple anomalies that has more than one identifying feature and due to a single known causative factor [1]. A syndrome also means that there is a specific, recognisable pattern of abnormalities according to each causative factor. The aetiological factor could be a mutant gene, chromosomal abnormality or an environmental factor, such as a teratogenic drug or addictive substance. However there are still many situations where the aetiology has not been understood [2]. The population risk of having a child with a minor congenital abnormality is estimated to be nearly $14 \%$ (skin tags, dimples, etc.). However, around $2-3 \%$ of newborns have a single major malformation, like cleft lip and palate or spina bifida, that will require extensive medical treatment. Under $1 \%$ of newborns have multiple serious malformations, including syndromes. However, the real occurrence of malformations is much higher than estimations, but many of them are aborted spontaneously, especially during the first trimester of pregnancy [3].

\section{Prenatal diagnosis}

In the recent years, imaging techniques have improved fast, as well as cytogenetic and molecular biology methods, and maternal serum markers analyses have become routine, so pregnant women with a high risk of having a baby with anomalies can be determined more commonly and enable the prenatal diagnosis of several congenital structural malformations and genetic disorders. The aim of all the prenatal diagnosis procedures is to detect birth defects such as chromosome abnormalities, genetic syndromes and other conditions in a foetus in utero. Detecting the abnormalities in utero allows us to make correct management of the pregnancy, prenatal and postnatal medical care and treatment, and also it is important for making informed decisions about continuing or terminating the pregnancy [4].

Prenatal tests can be divided into two groups: screening tests and diagnostic tests. Screening tests for congenital anomalies include maternal serum marker screening and ultrasound examination. Diagnostic testing includes invasive prenatal diagnosis techniques and foetal molecular analysis procedures without the need of invasive techniques (Table 1). Diagnostic methods like amniocentesis allow a specific diagnosis of chromosomal abnormality and also allow us to confirm single-gene syndromes that are suspected on prenatal ultrasonography by biochemical, molecular or cytomolecular techniques [5].

\section{Screening tests}

The traditional suggestion of quite a few of centres is that all pregnant women aged 35 years or older should be offered invasive prenatal testing [6]. However, maternal age alone is a relatively inadequate predictor of prenatal diagnosis. Down syndrome is more likely to occur at an older maternal age and the risk of having a baby with Down syndrome increases greatly after 35 years of age. Additional screening methods, such as maternal serum marker screening, should be included so the estimation of the risk will be more appropriate.

The first trimester screening involves PAPP-A (pregnancy associated plasma protein $\mathrm{A}$ ) and free HCG (human chorionic gonadotropin) levels in the maternal serum. These are combined with ultrasound examination, especially with nuchal translucency thickness and absence and/or presence of the nasal bone. The detection rate of these methods is about $85-90 \%$ in regard to trisomy 21 and 18, with a false-positive rate of $5 \%$. In recent years, a new biochemical marker, ADAM-12 (a disintegrin and metalloprotease-12) is added to the first trimester screening. The combination of ADAM-12, PAPP-A, HCG and NT measurements increases the detection rate to $97 \%$ with a false-positive rate of $1 \%$ [4].

Table 1 Prenatal tests

\begin{tabular}{ll}
\hline Screening tests & Maternal serum screening \\
- First trimester & - Second trimester \\
& Ultrasound \\
- Routine obstetric ultrasound scan & - Targeted ultrasound scan \\
- Doppler studies & - Foetal echocardiography \\
Magnetic resonance imaging (MRI) & Invasive prenatal diagnosis techniques \\
- Chorion villus sampling \\
- Amniocentesis \\
- Cordocentesis \\
Diagnostic tests \\
New approaches: foetal molecular analysis \\
procedures without the need of invasive \\
techniques
\end{tabular}


In the second trimester, triple screening is mostly used and it includes maternal serum $\alpha$-fetoprotein (MSAFP), unconjugated estriol and human chorionic gonadotropin (hCG) [7]. The detection rate of this combination of markers is approximately $60 \%$ in regard to trisomy 21 , with a false-positive rate of approximately 4\% [8]. Maternal urine human chorionic gonadotrophin $\beta$-core fragment (HCG $\beta \mathrm{cf}$ ) is also a potential marker in urine screening for foetal Down syndrome in the second trimester [9]. Measuring inhibin A in maternal serum, in combination with measurements of alpha-fetoprotein and the $\beta$ subunit of human chorionic gonadotropin (quadruple screening), can also be used for the detection of Down syndrome [10].

\section{Diagnostic tests}

Invasive prenatal diagnosis techniques have been applied for more than 20 years as a reliable method for couples with various risk factors [5]. In the recent years, ultrasonography techniques have improved fast and the maternal serum marker analyses have become routine, so those pregnant with a high risk can be determined more readily. Also, the invasive prenatal diagnostic methods are using more frequently in order to diagnose such risky cases effectively and early [11].

The main prenatal diagnostic methods are chorion villus sampling, amniocentesis and cordocentesis. Chorion villus sampling and cordocentesis require more experience and the complication rates and foetal loss rates are higher than amniocentesis $[12,13]$. While offering invasive diagnostic techniques to a pregnant woman, the risk factors and indications must be determined carefully. The main risk factors when identifying cases are: advanced maternal age, abnormal screening markers in the maternal serum, abnormal ultrasonography findings, and previous history of a foetus/child with chromosomal abnormalities or congenital anomalies, as mentioned in the previous article [14].

\section{Methods of invasive prenatal cytogenetic diagnosis}

The incidence of chromosomal disorders is about $0.5 \%$ in live newborns [15, 16]. Chorionic villus, amniocytes or umbilical blood cell sampling during pregnancy provide reliable methods for performing prenatal diagnoses. In some European countries more than $10 \%$ of the pregnant population undergoes invasive prenatal testing [17].

Prenatal sampling criteria were as follows:

- Advanced maternal age (greater than or equal to 35 years)

- Abnormal screening markers

- Abnormal ultrasound findings
- Previous history of a foetus/child with chromosomal abnormalities or congenital anomalies

- Family history of chromosomal abnormalities or congenital anomalies

- Carrier of X-linked recessive disorders

- Patient anxiety

\section{Chorionic villus sampling}

Chorion villus sampling is used routinely as a first-trimester diagnostic procedure for foetal genetic disease. Chorion villus sampling had become widely used worldwide by the early 1980 s.

The procedure is generally done late in the first trimester, most often between the 10th and 12th weeks. Use as early as 8 weeks in special circumstances has been described. About 8-10 mg (wet weight) chorion villus samples were obtained transabdominally. A sample of the developing placenta (trophoblast cells) is obtained for analysis. There are two approaches to chorion villus sampling: transabdominal and transcervical. Both methods are efficacious, and the choice is in most cases dependent upon physician preference. Transcervical chorion villus sampling has a higher incidence of spontaneous pregnancy loss, but it is the preferred method if the placenta is posterior or if the bowel inhibits a transabdominal approach [18]. These procedures should be performed under continuous ultrasound monitoring, by 'freehand' technique or using a needle-guide attached to the ultrasound probe. Chorion villus sampling is a technically more difficult procedure to perform than amniocentesis, and it has been suggested that 100-400 chorion villus samplings are needed before the learning curve reaches a plateau. With appropriate technical equipment, an operator with sufficient practical experience may decide on the sampling method in each case. In a UK survey, 98\% used the transabdominal approach [19]. The main advantage of chorion villus sampling is early and definitive chromosomal analysis [20]. One study reported a $0.8 \%$ greater loss rate with chorion villus sampling than with amniocentesis, and a cytogenetic diagnosis rate of $97.8 \%$ [21]. Apart from a risk of miscarriage, there is a risk of infection and amniotic fluid leakage. Chorion villus sampling, on the other hand, has been linked to limb reduction defects, although the evidence remains conflicting. After 10 weeks there was no increased risk of limb reduction defects, while the evidence below 10 weeks of gestation is less substantial [22]. Placental mosaicism and contamination by maternal tissue can be seen [23]. Mosaicism is detected in approximately $1 \%$ of chorion villus samples. True chromosomal mosaicism is when two or more abnormal cells lines are detected in two or more culture flasks from the same individual. 


\section{Amniocentesis}

Amniocentesis remains the most common invasive prenatal diagnostic procedure today. Amniocentesis was first introduced into obstetric practice as a means of detecting the severity of rhesus (Rh) isoimmunisation about 50 years ago [24]. Amniocentesis was first introduced for foetal sex determination by Serr et al., Fuchs and Riis in the 1950s [25, 26]. In 1983, Jeanty reported a technique of amniocentesis "under ultrasound vision" [27]. Amniocentesis for genetic diagnosis is typically performed between 16 and 18 weeks' gestation, which is when the procedure is safest. However, it can be performed from 14 to 20 weeks. Early amniocentesis is defined as amniocentesis performed between 9 and 14 weeks. The application of amniocentesis in the earlier weeks leads the higher pregnancy loss rates [28]. Traditionally, the indications for both chorion villus sampling and amniocentesis have been very similar, with advanced maternal age being the principal one. Advanced maternal age used to be the most common indication for invasive prenatal diagnosis. Other indications include an abnormal screening markers, abnormal ultrasound findings and a previous pregnancy with a chromosomal abnormality.

During amniocentesis, a needle (20-25 G) is inserted into the amniotic sac using ultrasound guidance, and about $20 \mathrm{ml}$ amniotic fluid is aspirated. Local anaesthesia is not necessary. Foetal viability should always be checked before and after the procedure. If the patient is Rh-negative, then 250 IU of anti-D immunoglobulin should be administered. The major risk of this procedure is miscarriage, which is estimated at $0.5-1 \%[17,18]$. The other risks are maternal infection, injuries of foetus, preterm delivery and transient amniotic fluid leakage [23]. Long-term complications include respiratory distress and isoimmunisation. Karyotype analysis of cells by culture is usually available in more than 2 weeks' time.

\section{Cordocentesis: foetal blood sample}

Cordocentesis seems to be a widely accepted method for prenatal diagnosis.

Cordocentesis is a diagnostic genetic test that examines blood from the foetal umbilical cord to detect foetal abnormalities. This method is performed no earlier than 17 weeks into pregnancy and is usually performed at 20 weeks of gestation or later by obtaining $0.5-1 \mathrm{ml}$ foetal blood from the umbilical vein. The major risks of this procedure are miscarriage, foetal death, premature birth, bleeding and foetal bradycardia [29]. Cordocentesis requires more experience and foetal loss rate is high $[12$, 13]. Foetal loss is the primary risk associated with cordocentesis and occurs in $1-2 \%$ of procedures. However, when quick results are required, cordocentesis can be performed, since it is highly safe, with a low complication frequency. In addition, infection, blood loss at the puncture site and premature rupture of membranes give risks similar to amniocentesis. For cytogenetic analysis, 0.5-1 $\mathrm{ml}$ foetal blood was taken using a heparinised syringe. Cordocentesis testing has a turnaround time of about $72 \mathrm{~h}$ and can detect chromosomal abnormalities.

\section{New approaches: foetal molecular analysis procedures without the need for invasive techniques}

Besides these invasive diagnostic tests, in the recent years the discovery of circulating cell-free foetal nucleic acids in maternal plasma has developed a new point of a view for non-invasive prenatal diagnosis. These new approaches have been based mainly on the detection of foetal nucleated cells in maternal blood, the isolation of foetal trophoblastic cellular elements shed into the uterine cavity and the endocervical canal, and the analysis of foetal genetic material present in maternal plasma [30, 31].

Invasive procedures have certain risks associated with them. On the other hand, non-invasive prenatal diagnosis gives ability to obtain the necessary genetic information from the foetus.

The first study on the cell-free foetal DNA (ffDNA) in maternal blood as a marker for non-invasive prenatal diagnostics aimed to detect sequences of the Y-chromosome as a marker of the male foetus in the blood of pregnant women to sex-linked prenatal diagnosis [32]. The sensitivity of Y-chromosome loci by the 7th week of gestation by standard polymerase chain reaction (PCR) was 95\%; while using real-time PCR, the sex of an embryo can be determined at the 5 th week of development with $100 \%$ accuracy. In the presence of male foetal cells among 12,800 cells of the mother can indicate a positive result.

Lo and colleagues described the use of ffDNA to detect the RHD gene in RhD-negative pregnant women [33]. Li et al. [34] carried out investigations to identify the $\mathrm{Rh}$ antigen, Rh-D foetal blood in Rh-negative women, which form a risk group. The detection of such a condition could result in activities as early as possible towards the prevention of $\mathrm{Rh}$ conflict between mother and foetus.

The technique used by Hyland et al. [35] can detect ffDNA in maternal plasma by real-time PCR. Cell-free foetal DNA involves about $4-6 \%$ of all cell-free DNA in the maternal circulation [33]. Internal controls are used to confirm the presence of foetal DNA to minimise falsenegative results and to reliably determine foetal DNA as early as 7 weeks after conception. Since only male foetuses could be detected by the SRY gene, Hyland and colleagues 
also utilised the RASSF1A gene to confirm the presence of foetal DNA from female fetuses [35]. By determining the foetal RHD status, they could predict with $100 \%$ accuracy compared with the infant's serotype, determined from cord blood after delivery. In rare cases, they failed to determine foetal status. The ffDNA can be applied more broadly in determination of foetal RHD status. The timely identification of foetal chromosomal anomalies is an important function of prenatal diagnosis [36]. The level of ffDNA in maternal plasma and serum increased on average twofold when a foetus had Down syndrome. Cell-free foetal DNA in other aneuploidies has changing levels. For example, in the case of trisomy of chromosome 13 it is increased, but remained low in trisomy 18. Pathology of the placenta is given as a possible reason for changing the concentration of ffDNA during the development of a fetus with abnormal karyotype.

Interphase fluorescence in situ hybridisation (FISH) analysis of floating maternal blood cells can identify foetal trisomy of chromosomes 21, 18, X, and Klinefelter syndrome (47, XXY) [37-39]. Thus, the study of 42,312 nuclei of cells isolated from 40 women's blood, for the purpose of prenatal diagnosis at different stages of pregnancy (10-27 weeks), allowed the detection of Down syndrome in two cases, which were later confirmed by amniocentesis [39]. The genders of all foetuses with karyotype 46, XX, and five of the 16 foetuses with male karyotype were accurately identified. However, in one case it failed to detect a foetus with Edwards' syndrome of aberrant cells among 640 sorted cells. In other observations, chromosomal abnormalities of the foetus were missing according to FISH and subsequent karyotyping amniocytes. Only single cases of prenatal diagnosis of aneuploidy were reported in most publications. This test has yet to lower the sensitivity and specificity compared with those of invasive techniques. The main problem remains as the low concentration of foetal cells in the enriched fraction, which does not react with DNA hybridisation probes. Therefore, a limited number of cells was analysed, which increases the probability of error. There were certain difficulties in determining the sex of the fetus. In a study of the DNA of sorted cells by PCR amplification of Y-specific sequences, foetal sex at 8-19 weeks of pregnancy was identified in $94-100 \%$ of cases [40]. This approach is not superior to existing screening tests since it is still considered as experimental and informative. Significant complexity and high cost of sorting foetal cells prevents its use in clinical practice as a screening for aneuploidy.

Although newer techniques such as methylation-dependent PCR and digital PCR offer promise, the non-invasive diagnosis of Down syndrome and other aneuploidies still remains challenging [41]. The novel molecular markers for the detection of chromosomal imbalances in the foetus, as well as successful experiments carried out to detect foetal single nucleotide polymorphisms and point mutations, are currently being investigated in addition to measuring the concentration of ffDNA in maternal blood. There are some studies indicating non-invasive prenatal diagnosis of Huntington's disease [42], cystic fibrosis [43] and other conditions. The detection of the SRY gene leads to the determination of foetal sex in women at risk of carrying a foetus with an X-linked condition [44].

Compared with a group of women with normally proceeding pregnancies, a nearly fivefold increase in ffDNA was reported in the blood of mothers with pre-eclampsia [45]. Further pathological examination revealed not only an increase in the concentration of cell-free DNA of the foetus, but also a significant increase in cell-free DNA of the mother, for which an increase in both figures indicates the severity of the disease. In addition, the concentration of cell-free DNA of the foetus increased long before the first clinical symptoms. An increased concentration of foetal DNA may be the result of necrosis and apoptosis of the placenta, since the plasma DNA is a marker of cell death. A problem of renal and hepatic function observed with pre-eclampsia decreases the excretion of circulating DNA from maternal blood.

Increasing the concentration of ffDNA in maternal blood is seen in other disorders of pregnancy, such as spontaneous miscarriage in the first trimester, pre-term labour [46], and the true increment of the placenta [47].

It is possible to determine the karyotype of foetal cells circulating in the mother's bloodstream. In late pregnancy, one foetal erythroblast corresponds to 10,000 maternal nucleated cells. With the help of modern immunofluorescent or magnetic modules for flow cell sorting (FACS, MACS, and others), the fraction of foetal cells can reach $10 \%$ [37]. To isolate erythroblasts, fluorochrome-labelled or iron particles with monoclonal antibodies to proteins [membrane proteins - transferrin receptor (CD71), glycophorin a receptor and thrombospondin] are used [38]. First, blood cells are centrifuged in a triple density gradient, and in some cases, are carried out by means of nuclear dyes in selection of cells containing a nucleus. The negative sorting of CD45-positive lymphocytes is also recommended. In addition to erythroid cells in maternal blood, there are foetal lymphocytes and granulocytes, as well as trophoblastic cells, but they are inappropriate for cytogenetic studies [37, 38].

The determination of foetal RHD status is becoming available as a clinical tool, and is likely to be the first of many applications of non-invasive prenatal testing in the future.

Modern technologies permit the use the new knowledge into practical medicine. Further study of nucleic acids in maternal blood is necessary in order to develop new markers for non-invasive prenatal diagnosis of pathological conditions of the foetus at an early stage of their occurrence. 
It would not be possible here to mention all the syndromes that can determined by prenatal diagnosis. The followings are the syndromes that we usually experience in the clinic and while giving genetic counseling and also we mentioned the common syndromes that we come across at the postnatal diagnosis.

\section{Down syndrome (trisomy 21)}

Trisomy 21 is the most common chromosomal abnormality in humans. Approximately $0.45 \%$ of human conceptions are trisomic for chromosome 21 (Fig. 1) [48]. The frequency of trisomy 21 in the population is 1 in $700-1,000$ of live births [49]. Characteristic facial features and hypotonia are present in almost all patients; approximately $50 \%$ suffer from congenital cardiac anomalies [50]. The features of this syndrome include mental retardation, retarded growth, flat hypo- plastic face, epicanthic skin folds, low-set ears with prominent antihelix, thickened tongue, laxness of joint ligaments, pelvic dysplasia, broad hands and feet, single palmar crease, lenticular opacities and heart disease (Fig. 2).

\section{Edwards' syndrome (trisomy 18)}

Trisomy 18 is the second most common autosomal trisomy after Down syndrome. This syndrome characterised by severe psychomotor and growth retardation, microcephaly, microphthalmia, micrognathia, cardiac and urogenital anomalies (Figs. 3, 4). The prevalence is approximately 1 in $3,000-8,000$ [51]. The risk of trisomy 18 is known to increase as the age of the child's mother at the time of pregnancy increases [52]. The risk of trisomy 18 is also associated with increasing paternal age.

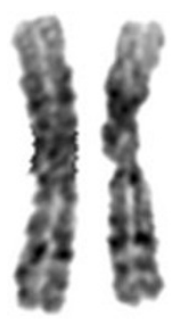

1

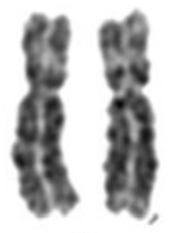

6

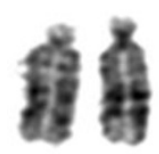

13
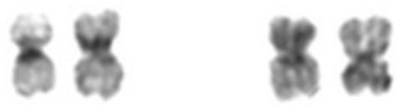

19

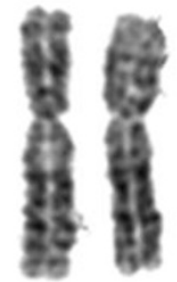

2

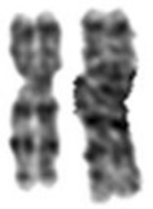

7

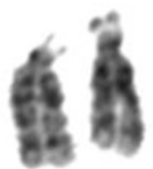

14

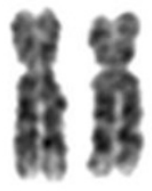

8

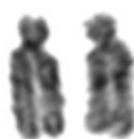

15

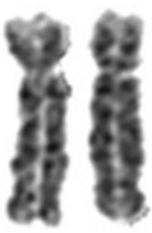

4

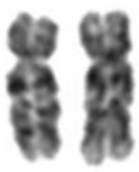

10

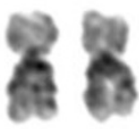

16

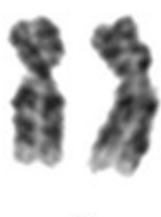

9

11
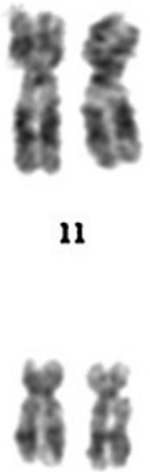

17

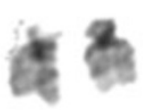

21
22

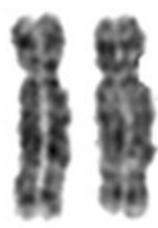

5

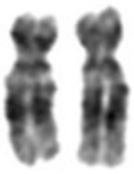

12

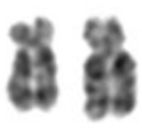

18

Fig. 1 Karyotype of a patient with trisomy 21 


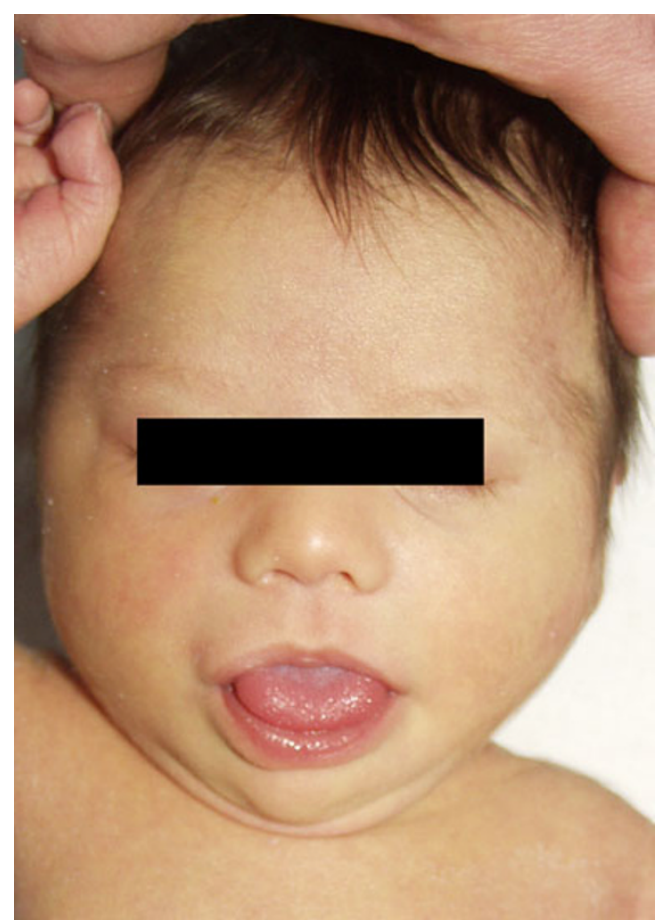

Fig. 2 The craniofacial apperance of a patient with trisomy 21

\section{Patau syndrome (trisomy 13)}

The trisomy 13 syndrome typically includes central nervous system malformations, (holoprosencephaly and arinencephaly) with consequent severe psychomotor dysfunction and convulsions. This syndrome is characterised by defects of eye (microphthalmia), polydactyly, cleft lip, scalp skin defect and cardiac defects. The incidence is approximately 1 in 5,000 births. It is the third most frequent trisomy among live births [53].

\section{Turner syndrome (monosomy X)}

Turner syndrome is the result of total or partial monosomy of the X-chromosome (Fig. 5). This syndrome is characterised by short stature and gonadal failure. Other commonly reported features include lymphedema, renal anomalies, cardiac defects, webbed neck, and low posterior hairline. The birth prevalence of Turner syndrome has been estimated to be from 1 in 2,000 to 1 in 5,000 female live births.

\section{Prenatal diagnosis of Down syndrome, Edwards syndrome, Patau syndrome and Turner syndrome}

The majority of chromosome abnormalities identified in prenatal samples are trisomy for chromosomes 13, 18, 21 and sex chromosome aneuploidies (Patau, Edwards and Down syndromes, and the less severe Turner and Klinefelter syndromes). Trisomy 21 is the predominant reason for pregnant women who underwent prenatal diagnosis [54, 55].

In recent years, first-trimester screening programmes have been developed and recent studies concluded that the sensitivity of first trimester screening (11-14 weeks) is much higher than second trimester tests (Table 2) [56]. PAPP-A and human chorionic gonadotropin combination has a detection rate of $60-65 \%$ for trisomy 21 [57]. According to another study in the first trimester, screening by a combination of ultrasound markers and maternal serum $\beta-\mathrm{hCG}$ and PAPP-A can identify up to $97 \%$ of foetuses with trisomy 21 and other major chromosomal abnormalities [58]. About 75\% of trisomy 21 foetuses have increased nuchal translucency thickness, $70 \%$ have absent nasal bone and $25 \%$ have maxillary hypoplasia [59].

The risk for many of the chromosomal defects increases with maternal age. As in recent years maternal age has increased into middle age, the frequency of chromosomal abnormalities increases. A maternal age of 35 years at delivery has been the medicolegal standard in the USA and Europe for more than 20 years and this high risk group constituted $5 \%$ of the pregnant population [60].

Turner syndrome may be diagnosed or suspected prenatally because of ultrasonographic evidence of cystic hygroma, oedema, and non-immune hydrops. Ultrasonography showing a cardiac defect (coarctation of aorta), intrauterine growth retardation, renal anomalies (horseshoe kid-

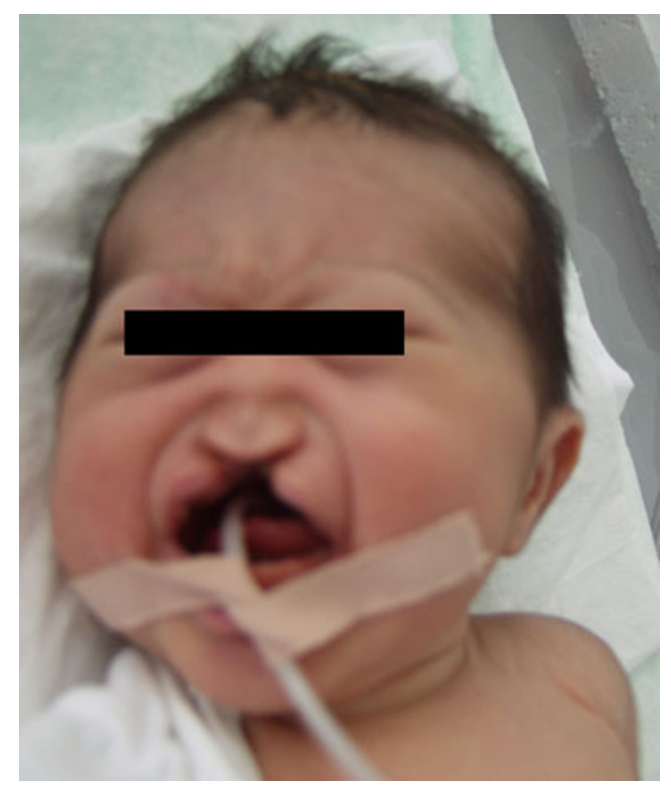

Fig. 3 The craniofacial apperance of a patient with trisomy 18 


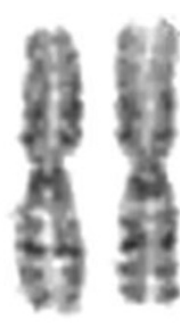

1

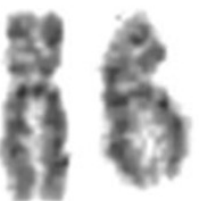

6

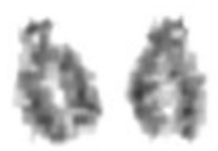

13
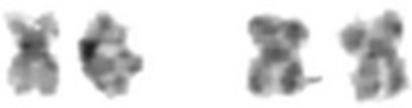

20

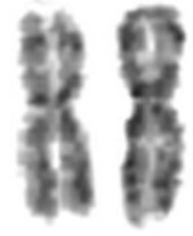

3

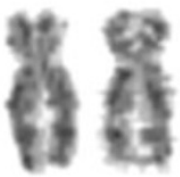

8

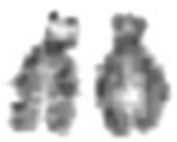

15

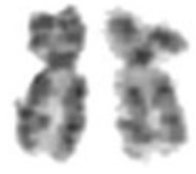

9

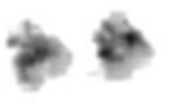

21
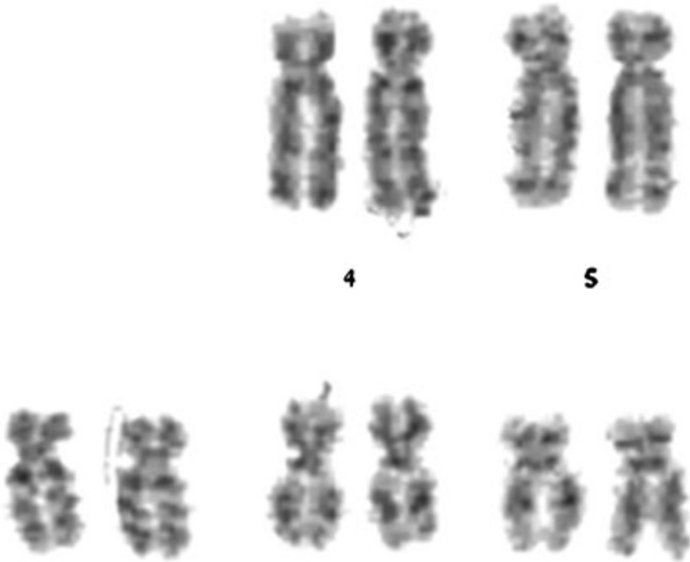

10

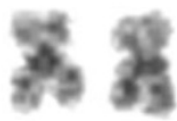

16

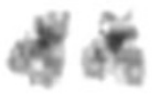

22

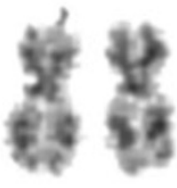

11

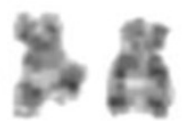

17

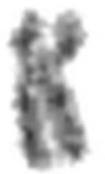

$\mathrm{x}$
S

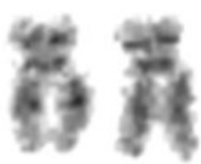

12

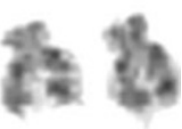

18

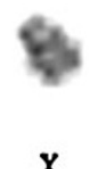

Fig. 4 Karyotype of a patient with trisomy 18

ney) or short limbs also may suggest Turner syndrome. Besides ultrasonographic evidence, the maternal serum AFP and uE3 concentrations were slightly reduced in pregnancies affected with Turner syndrome as has been reported previously. So, women with an increased risk of Down syndrome, based on maternal serum marker screening, should be informed that Turner syndrome may be a possibility, even in the absence of ultrasonographic findings [61]. If an abnormality associated with Turner syndrome is diagnosed by ultrasonography or if multiple marker screening is positive, the recommended follow-up is invasive prenatal diagnostic techniques for foetal karyotyping [62] (Table 3).

\section{DiGeorge syndrome}

DiGeorge syndrome is one of the most common microdeletion syndromes. It is characterised by hypoplasia or aplasia of the thymus and parathyroid glands, a conotruncal heart defect (tetralogy of Fallot, type B interrupted aortic arch, truncus arteriosus, right aortic arch and aberrant right subclavian artery) and various craniofacial dysmorphism. It is the second most frequent chromosomal abnormality associated with congenital heart defects. The estimated incidence of the submicroscopic deletion of chromosome 22q11 is 1 in 4,000 live births $[63,64]$. This syndrome is caused by the developmental defect of the third and fourth pharyngeal pouches [65]. The submicroscopic deletion of chromosome 22 that is detected by FISH is frequently associated with the syndrome.

Prenatal diagnosis of a $22 \mathrm{q} 11$ deletion was reported in a foetus with a known affected sister and father [66], in the foetus of a patient with the deletion and veloocardiofacial syndrome [64] in the foetus of a mother with congenital heart disease [67], and in a foetus with interrupted aortic arch type B [68]. Thus, with ultrasonographic evidence and/ 


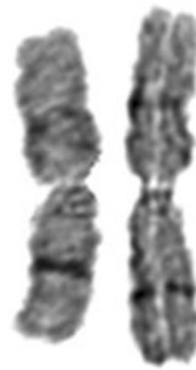

1

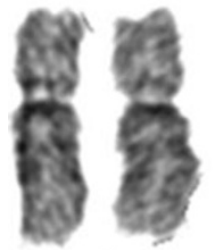

6

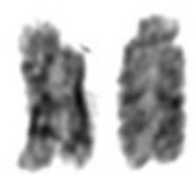

13

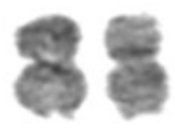

19
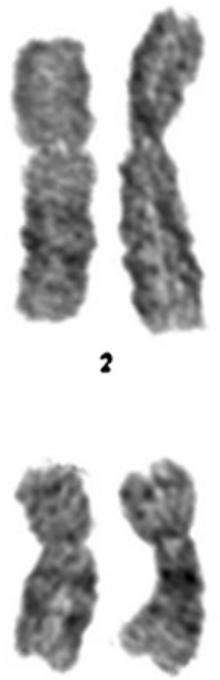

7

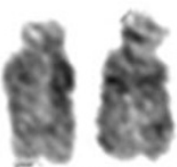

14

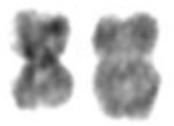

20

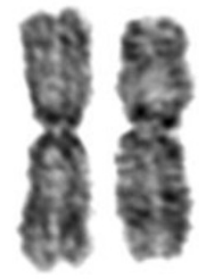

3

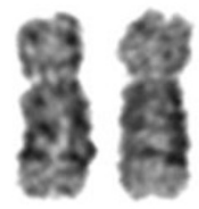

8

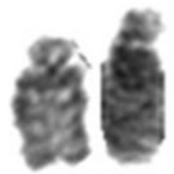

15

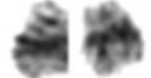

21

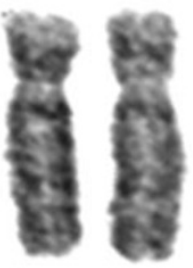

4
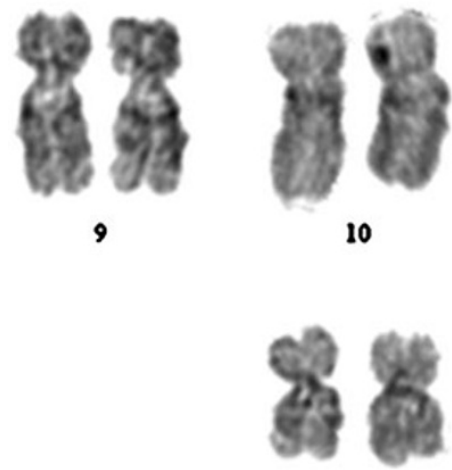

16

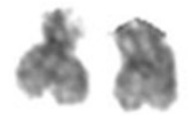

22

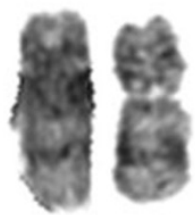

11

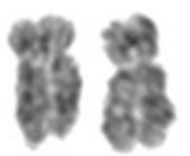

17

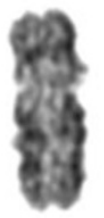

x

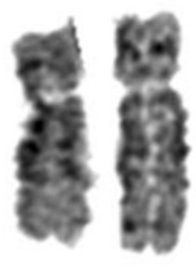

S

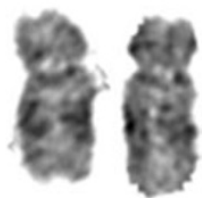

12

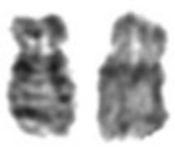

18

$\mathbf{Y}$

Fig. 5 Karyotype of a patient with Turner syndrome

or familial history, prenatal diagnosis of Di George syndrome is possible with FISH.

\section{Fragile X syndrome}

Fragile X syndrome (FXS) is the leading inherited cause of intellectual disability, accounting for $40 \%$ of all X-linked mental retardation [69]. The prevalence of FXS is 1 in 4,000 males and 1 in 8,000 females. FXS occurs in individuals with an FMR1 full mutation. Postnatal and prenatal diagnosis is feasible by direct DNA analysis. A new approach to prenatal diagnosis of FXS in amniotic fluid cells is described, using a rapid and simple antibody test on uncultured amniotic fluid cells [70].

Prenatal diagnosis of the FXS can be performed either on chorionic villi or amniotic fluid cells. In both tissues, a direct DNA analysis (Southern blotting) of the mutation responsible for the FXS is carried out [71, 72].

\section{Cystic fibrosis}

Cystic fibrosis (CF) affects epithelia of the respiratory tract, exocrine pancreas, intestine, male genital tract, hepatobiliary system, and exocrine sweat glands, resulting in complex multisystem disease. CF is caused by mutations in the gene encoding CF transmembrane conductance regulator [73]. The incidence of CF varyies from 1 in 2,500 to 1 in 5,000 (carrier rate 1 in 25-35) [74]. The disease may be revealed by foetal bowel hyperechogenicity during routine ultrasonography in the second trimester of pregnancy. However, foetal bowel hyperechogenicity is not specific for CF. The potential of hyperechogenic foetal bowel to act as a hallmark for prenatal CF screening in the general population is controversial [75]. Diagnostic investigations are based on screening for CF-causing mutations, foetal karyotyping, and screening for infections. To date, almost 900 mutations have been described throughout the CFTR gene, but very few deletions have been identified [76]. 
Table 2 Sensitivity of first-trimester screening programs, for a 5\% false positive rate. (Taken from [58])

\begin{tabular}{ll}
\hline Screening programme & Sensitivity (\%) \\
\hline Maternal age (years) & 30 \\
Maternal age+AFP & 40 \\
Maternal age+AFP+bhCG & 60 \\
Maternal age+AFP+bHCG+uE3 & 70 \\
Maternal age+AFP+bhCG+inhibin A & 70 \\
Maternal age+AFP+bhCG+uE3+inhibin A & 75 \\
Maternal age+nuchal translucency & 75 \\
Maternal age+PAPP-A+free bhCG & 65 \\
Maternal age+PAPP-A+free bhC+nasal bone & 93 \\
\hline
\end{tabular}

Conventional PCR-based methods usually detect deletions only when they are present in the homozygous state. Two relatively frequent large deletions have recently been described: $3120+1 \mathrm{kbdel} 8.6 \mathrm{~kb}$ was found in $13 \%$ of $\mathrm{CF}$ chromosomes in Israeli-Arab patients [77], and CFTRdele2,3 (21 kb) accounts for $1-6.4 \%$ of $\mathrm{CF}$ chromosomes in Slavic populations [78]. Screening for cystic fibrosis should be offered to families in which foetal hyperechogenic bowel is diagnosed at routine ultrasonography [75].

\section{Williams syndrome}

Williams syndrome (WS) is characterised by cardiovascular disease (elastin arteriopathy, peripheral pulmonary stenosis, supravalvular aortic stenosis, hypertension), distinctive facies, connective tissue abnormalities, mental retardation (usually mild), a specific cognitive profile, unique personality characteristics, growth abnormalities, and endocrine abnormalities (hypercalcemia, hypercalciuria, hypothyroidism, and early puberty). A recent study of WS reported a prevalence of 1 in 7,500 [79]. Increased foetal nuchal translucency and low maternal serum alpha-fetoprotein (MSAFP) can be determined in prenatal screening. Also, foetal ultrasound can reveal multicystic dysplastic kidney and congenital heart defects [80]. The inheritance pattern of this syndrome is autosomal dominant but most of the cases are de novo occurrences. Prenatal testing is clinically available and suitable for familial cases. FISH testing may be used to detect the microdeletion at $7 \mathrm{q} 11.23$, a region that includes approximately 17 genes (including the elastin gene and LIM-kinase 1 gene) [81]. Chorionic villus sampling or amniocentesis can be performed for FISH analysis.
Table 3 First and second trimester ultrasonographic findings of the trisomy 21, 13, 18 and Turner syndrome. (Derived from [2, 4])

\begin{tabular}{|c|c|c|c|c|}
\hline & $\begin{array}{l}\text { Trisomy } \\
21\end{array}$ & $\begin{array}{l}\text { Trisomy } \\
13\end{array}$ & $\begin{array}{l}\text { Trisomy } \\
18\end{array}$ & $\begin{array}{l}\text { Turner } \\
\text { Syndrome }\end{array}$ \\
\hline \multicolumn{5}{|l|}{ First trimester } \\
\hline Nuchal translucency & + & & & + \\
\hline $\begin{array}{l}\text { Absence of fetal } \\
\text { nasal bone }\end{array}$ & + & & & \\
\hline Low nasal bridge & + & & & \\
\hline $\begin{array}{l}\text { Small or absent } \\
\text { earlobes }\end{array}$ & + & & & \\
\hline Flat face & + & & & \\
\hline Hypoplastic maxilla & + & & & \\
\hline $\begin{array}{l}\text { Abnormal blood } \\
\text { flow velocity in } \\
\text { the foetal ductus } \\
\text { venosus }\end{array}$ & + & & & \\
\hline Omphalocele & & & + & \\
\hline Hypoplastic bladder & & + & + & \\
\hline Single umblical artery & & & + & \\
\hline $\begin{array}{l}\text { Intra-uterine growth } \\
\text { retardation }\end{array}$ & & + & + & + \\
\hline \multicolumn{5}{|l|}{ Second trimester } \\
\hline $\begin{array}{l}\text { Congenital heart } \\
\text { defects, } \\
\text { ventriculomegaly }\end{array}$ & + & + & + & + \\
\hline $\begin{array}{l}\text { Echogenic intracardiac } \\
\text { focus }\end{array}$ & + & + & + & \\
\hline Microcephaly & + & + & + & \\
\hline Holoprosencephaly & & + & & \\
\hline $\begin{array}{l}\text { Choroid plexus } \\
\text { cyst }>3 \mathrm{~mm}\end{array}$ & + & + & + & \\
\hline $\begin{array}{l}\text { Agenesis/hypoplasia } \\
\text { of corpus callosum }\end{array}$ & & & + & + \\
\hline $\begin{array}{l}\text { Enlarged cisterna } \\
\text { manga }>10 \mathrm{~mm}\end{array}$ & & & + & \\
\hline Dandy walker & & + & + & \\
\hline Cleft lip, cleft palate & & + & + & \\
\hline Micrognathia & & & + & \\
\hline Diaphragmatic hernia & & + & + & \\
\hline $\begin{array}{l}\text { Duodenal atresia, } \\
\text { pyloric stenosis, } \\
\text { imperforate anus }\end{array}$ & + & & & \\
\hline Encephalocele & & & + & \\
\hline Omphalocele & & + & + & \\
\hline Polydactily, syndactily & & + & & \\
\hline $\begin{array}{l}\text { Thickened nuchal fold } \\
16-18 \text { week }>5 \mathrm{~mm} \\
18-24 \text { week }>6 \mathrm{~mm}\end{array}$ & + & + & + & + \\
\hline Cystic higroma & + & + & + & + \\
\hline $\begin{array}{l}\text { Duedonal atresia and } \\
\text { echogenic bowel }\end{array}$ & + & + & + & \\
\hline Kidney defects & + & + & + & + \\
\hline Ventriculomegaly & + & & & \\
\hline \multicolumn{5}{|l|}{$\begin{array}{l}16-20 \text { weeks } \\
10-15 \mathrm{~mm}\end{array}$} \\
\hline $\begin{array}{l}\text { Short metacarpal } \\
\text { and phalanges }\end{array}$ & + & & & \\
\hline Equinavarus deformity & & + & + & \\
\hline Rocker-bottom feet & & & + & \\
\hline
\end{tabular}


Table 3 (continued)

\begin{tabular}{lllll}
\hline & Trisomy & Trisomy & Trisomy & Turner \\
& 21 & 13 & 18 & Syndrome \\
Fifth finger & + & & & \\
clinodactily & & & & + \\
$\begin{array}{c}\text { Intra-uterine growth } \\
\text { retardation }\end{array}$ & + & & & \\
\hline
\end{tabular}

\section{Achondroplasia}

Achondroplasia is the most common type of human dwarfism. The estimated incidence is between 1 in 10,000 and 1 in 30,000 live births [82-84]. The syndrome is characterised mainly by disproportionately short stature, macrocephaly, spinal stenosis, brachidactyly, and three pronged fingers (trident) [85]. The syndrome has an autosomal inheritance pattern, but more than $90 \%$ of the cases represent a fresh gene mutation and these cases are strongly associated with increased paternal age. Mutations in the gene encoding fibroblast growth factor receptor 3 (FGFR3) have been found as a causative factor. The prenatal ultrasonography allows the detection of skeletal dysplasias, but most of them appear in the second trimester or later [85]. In prenatal ultrasound, micromelia is the most predominant finding. The frontal bossing and depressed nasal bridge can also be recognised (Figs. 3, 4). Occasionally more subtle anomalies, such as the trident hand (an increased space between the third and fourth digit), can be observed (Figs. 3, 4). Besides these, a ratio of femur length to abdominal circumference of $<0.16$ with a hypoplastic thorax can be used as indicative of a skeletal dysplasias [86]. Chorionic villus sampling or amniocentesis can also be performed with pregnancies at risk for FGFR3 mutation, and a non-invasive method using maternal plasma and quantitative fluorescent PCR (QF-PCR) may be useful for the diagnosis of the foetal achondroplasia. Lim et al. [87] used circulating foetal DNA (cf-DNA) in maternal plasma, and they mentioned the QF-PCR method is suitable for detection of the FGFR3 mutation (G1138A) causing achondroplasia.

\section{Osteogenesis imperfecta}

Osteogenesis imperfecta is a heterogeneous group of genetic disorders characterised by severe bone fragility, abnormal ossification and multiple fractures. The incidence in the population is nearly 1 in 10,000 and is maintained by a high rate of new mutations $[88,89]$. The phenotype of the patients results from mutations in either of the two genes, COL1Al and COL1A2. These genes encode collagen 1, which is an important structural protein in bone [90]. The early prenatal diagnosis of lethal skeletal dysplasias is possible with the guidance of ultrasonographic evidence and/or familial history. In prenatal ultrasound examination sonographic findings include broad, short fractured long bones and significant decrease in bone ossification.

\section{Conclusions and outlook}

The development of the imaging techniques, as well as cytogenetic and molecular biology methods with maternal serum marker analyses, has opened up new opportunities in genetic prenatal diagnosis for all pregnancies and especially pregnancies at high risk of resulting in a baby with an abnomality. Detecting the abnormalities in utero enables the correct management of the pregnancy, prenatal and postnatal medical care and treatment, and also it is important for making informed decisions about continuing or terminating the pregnancy.

The main invasive prenatal diagnostic methods are chorion villus sampling, amniocentesis and cordocentesis. These standard methods are based on culturing foetal cells and then implementing classical and molecular cytogenetic techniques or molecular methods. Amniocentesis remains to be the most common invasive prenatal diagnostic procedure today [91], although the miscarriage risk is estimated at $0.5-1 \%[92,93]$. The other risks are maternal infection, injuries to the fetus and preterm delivery. Chorion villus sampling and cordocentesis require more experience, and the complication rates and foetal loss rates are higher than amniocentesis [12, 13]. Besides these invasive diagnostic tests, the discovery of circulating foetal DNA in maternal plasma has developed a new point of a view for non-invasive prenatal diagnosis. The main risk factors that using when identifying cases at risk of having a baby with chromosomal abnormality and/or genetic disorder and

Table 4 Top ten most common single-gene Mendelian disorders in the UK and their frequency per 1,000 births. (Taken from [100])

\begin{tabular}{ll}
\hline Familial combined hyperlipidemia & 5.0 \\
Familial hypercholesterolemia & 2.0 \\
Dominant otosclerosis & 1.0 \\
Adult polycystic kidney disease & 0.8 \\
Multiple exostoses & 0.5 \\
Huntington's disease & 0.5 \\
Fragile X syndrome & 0.5 \\
Neurofibromatosis & 0.4 \\
Cystic fibrosis & 0.4 \\
Duchenne muscular dystrophy & 0.3 \\
\hline
\end{tabular}


suggesting the use of prenatal diagnosis methods are: advanced maternal age, abnormal screening markers in maternal serum, abnormal ultrasonography findings, previous history of a foetus/child with chromosomal abnormalities or congenital anomalies [94]. In most countries, including Turkey, the suggestion is that all pregnant women who are 35 years of age or older should be offered invasive prenatal testing [3].

In conclusion, maternal screening tests are directive and prenatal ultrasonography is capable of recognising syndromic patterns of anomalies. Invasive prenatal tests require experience and have various complications, but we do not have enough experience in alternative prenatal diagnostic tests, such as testing circulating cell-free foetal nucleic acids in maternal plasma.

The majority of abnormalities identified in prenatal samples are trisomy for chromosomes 13, 18, 21 and sex chromosome aneuploidies. In some countries, especially in Europe, the recommended diagnostic techniques include rapid FISH, MLPA (multiple ligation PCR amplification) and QF-PCR [4]. These methods have some advantages. The small sample amount is sufficient and the results are obtained in few days. Also, these approaches include classical cytogenetic analysis when there are suspicions for other chromosomal aberrations. In Turkey, most of the laboratories perform rapid FISH, MLPA and QF-PCR with standard methods that are based on culturing foetal cells respectively in order to achieve rapid pregnancy management and not to miss other chromosomal aberrations.

All people have a risk of diseases due to genetic mutations. A higher prevalence of genetic diseases in particular communities may exist, however, due to some social or cultural factors.

Generally, the incidence of chromosomal disorders does not change according to the population. Nearly $0.5 \%$ of all newborns have a chromosomal abnormality and $7 \%$ of all stillborns have a chromosomal abnormality [95]. The main difference between the populations involves the single-gene disorders, especially the autosomal recessive ones, due to consanguineous marriages. The rate of consanguineous marriage varies in relation to various factors, such as race, characteristics of population, religion and moral features in different countries [96]. Gene frequency and genetic structure are changed by this kind of marriage [97]. The results of many studies show that the rate of consanguinity among parents of children with rare recessive diseases is quite above Turkey's average [98]. Turkey has a high rate of consanguineous marriages. Different studies indicate that today $20-25 \%$ of marriages are consanguineous [98], especially in the Eastern part of Turkey, where this rate increases up to $34.4 \%$ [97].
There are no regular incidence studies for genetic diseases in Turkey. The most common disorders are cyctic fibrosis, beta-thalasemia, sickle cell anemia, spinal musculer atrophy, infantile polycystic kidney disease, acondroplasia, Duchenne/Becker musculer dystrophy, and haemophilia A and B [99]. In the United Kingdom, incidence studies related with genetic diseases revealed the most common disorders as shown in Table 4 [100].

The ministry of health began to work on the studies that deal with the prevention of the genetic diseases in Turkey. The routine genetic diseases screening programmes for newborns in Turkey include metabolic diseases such as phenylketonuria, biotinidase deficiency and hypothyroidism, and besides these diseases, prenatal screening programmes have been applied for many years. Within the scope of these studies, the health institutions and organisations are applying various screening and diagnostic programmes besides the medical and genetic counselling service in order to prevent mentally and physically handicapped children [101]. Besides these health politics, various scientific work groups have been constituted within the Ministry of Health [102].

As a result, the control of genetic diseases should be based on an integrated and comprehensive strategy and it is essential that the Health Ministry should instigate collaborations to prevent genetic diseases. Intelligent political regulation in the healthcare sector must be arranged carefully and participation of the private sector should be provided. Awareness of the public about the basic principles of genetic diseases and genetic counselling should be raised because screening programmes need to be supported by public education. Also, the countries that have a high rate of consanguineous marriages must focus their attention on this subject besides autosomal recessive diseases. In the near future, the granting of "orphan" drug designation for the treatment of rare/orphan diseases will encourage initiatives to promote the development of appropriate drugs. This may provide therapeutic benefits to the patients and also somatic-cell gene therapy may play an important part in the management of genetic diseases in the future [96].

\section{References}

1. Moore KL, Persaud TV. The developing human: clinically oriented embryology. Philadelphia: Saunders; 2002. p. 168.

2. Jones KL. Smith's Recognizable patterns of human malformation. Philadelphia: Saunders; 1997. p. 3.

3. http://www.eurocat-network.eu/content/Special-Report-EnvRisk-I-and-II.pdf.

4. Stembalska A, Ryszard OE, Karolina P, Justyna G, Sasiadek MM. Prenatal diagnosis - principles of diagnostic procedures and genetic counseling. Folia Histochem Cytobiol. 2007;45 (Supp. 1):11-6. 
5. Han SH, An JW, Jeong GY, Yoon HR, Lee A, Yang YH, et al. Clinical and cytogenetic findings on 31,615 mid-trimester amniocenteses. Korean J Lab Med. 2008;28:378-85.

6. Haddow JE, Palomaki GE, Knight GJ, Cunningham GC, Lustig LS, Boyd PA. Reducing the need for amniocentesis in women 35 years of age or older with serum markers for screening. $\mathrm{N}$ Engl J Med. 1994;330:1114-8.

7. Palomaki GE, Knight GJ, McCarthy JE, Haddow JE, Donhowe JM. Maternal serum screening for Down Syndrome in the United States: a 1995 survey. Am J Obstet Gynecol. 1997;176:1046-51.

8. The Canadian Task Force on the Periodic Health Examination. Periodic Health Examination, 1996 update: 1. Prenatal screening for and diagnosis of Down syndrome. Can Med Assoc J. 1996;154(4):465-79.

9. Hsu JJ, Spencer K, Hung TH, Hsieh TT, Soong YK. Secondtrimester maternal urine human chorionic gonadotrophin $\beta$-core fragment concentrations in Asian pregnancies with fetal chromosomal abnormalities. Hum Reprod. 1999;14(9):2381-5.

10. Aitken DA, Wallace EM, Crossley JA, Swanston IA, van Pareren $\mathrm{Y}$, van Maarle $\mathrm{M}$, et al. Dimeric inhibin A as a marker for Down's syndrome in early pregnancy. $\mathrm{N}$ Engl J Med. 1996;334:1231-6.

11. Acar A, Balci O, Gezginc K, Onder C, Capar M, Zamani A, et al. Evaluation of the results of cordocentesis. Taiwan J Obstet Gynecol. 2007;46(4):405-9.

12. Lynch L, Berkowitz RL. Amniocentesis, skin biopsy, umbilical cord blood sampling in the prenatal diagnosis of genetic disorders. In: Reece EA, Hobbins JC, Mahoney MJ, editors. Medicine of the fetus and mother. Philadelphia: Lippincott; 1992. p. 641-52.

13. Lippman A, Tomkins DJ, Shime J, Hamerton JL. Canadian multicentre randomized clinical trial of chorion villus sampling and amniocentesis. Final report. Prenat Diagn. 1992;12:385-408.

14. Tseng JJ, Chou MM, Lo FC, Lai HY, Chen MH, Shih-Chu HE. Detection of chromosome aberrations in the second trimester using genetic amniocentesis: experience during 1995-2004. Taiwan J Obstet Gynecol. 2006;45(1):39-41.

15. Han XY, Jin L, Fan GS, Xiang Y, Liu XY, Cui QC. Fetal anomalies in second trimester in recent ten years: clinical analysis of 116 cases. Natl Med J China (Chin). 2009;89:10536

16. Cerrillo Hinojosa M, Yerena de Vega MC, Gonzalez Panzzi ME, Godoy H, Galicia J, Gutierrz Najar A. Genetic amniocentesis in high-risk populations. Experience in 3081 cases. Ginecol Obstet Méx. 2009;77:173-82.

17. Boyd PA, De Vigan C, Khoshnood B, Loane M, Garne E, Dolk $\mathrm{H}$, et al. Survey of prenatal screening policies in Europe for structural malformations and chromosome anomalies, and their impact on detection and termination rates for neural tube defects and Down's syndrome. BJOG. 2008;115:689-96.

18. Anderson CL, Brown CE. Fetal Chromosomal Abnormalities: Antenatal Screening and Diagnosis Am Fam Physician. 2009;79 (2):117-23.

19. Carlin AJ, Alfirevic Z. Techniques for chorionic villus sampling and amniocentesis: a survey of practice in specialist UK centres. Prenat Diagn. 2008;28:914-9.

20. ACOG Committee on Practice Bulletins. ACOG practice bulletin: screening for fetal chromosomal abnormalities. Obstet Gynecol. 2007;109(1):217-27.

21. Palomaki GE, Steinort K, Knight GJ, Haddow JE. Comparing three screening strategies for combining first- and secondtrimester Down syndrome markers. Obstet Gynecol. 2006;107 (2 pt 1):367-75.

22. Cederholm M, Haglund B, Axelsson O. Infant morbidity following amniocentesis and chorionic villus sampling for prenatal karyotyping. BJOG. 2005;112:394-402.
23. Alfirevic Z, Sundberg K, Brigham S. Amniocentesis and chorionic villous sampling for prenatal diagnosis. Cochrane Database Syst Rev. 2003;3:CD003252.

24. Royal College of Obstetricians and Gynaecologists. Amniocentesis and chorionic villus sampling. Guideline No. 8. London: RCOG Press; 2005.

25. Serr DM, Sachs L, Danon M. Diagnosis of sex before birth using cells from the amniotic fluid. Bull Res Council Isr. 1955;58:137.

26. Fuchs F, Riis R. Antenatal sex determination. Nature. 1956;177:330.

27. Jeanty P, Rodesch F, Romero R, Venus I, Hobbins JC. How to improve your amniocentesis technique. Am J Obstet Gynecol. 1983;146:593-6.

28. Benn PA. Advances in prenatal screening for Down syndrome: II first trimester testing, integrated testing, and future directions. Clin Chim Acta. 2002;324:1-11.

29. Preis K, Ciach K, Swiatkowska-Freund M. The risk of complications of diagnostic and therapeutic cordocentesis. Gin Pol. 2004;75(10):765-9.

30. Lo YMD, Rossa WKC. Noninvasive prenatal diagnosis of fetal chromosomal aneuploidies by maternal plasma nucleic acid analysis. Clin Chem. 2008;54:3 461-466.

31. Illanes S, Fattah SA, Soothill P. Review. Non-invasive prenatal diagnosis. Obstet Gynaecol. 2006;8:91-5.

32. Farina A, Caramelli E, Concu M, Sekizawa A, Ruggeri R, Bovicelli L, et al. Testing normality of fetal DNA concentration in maternal plasma at 10-12 completed weeks gestation: a preliminary approach to a new marker for genetic screening. Prenat Diagn. 2002;22:148-52.

33. Lo YM, Tein MS, Lau TK, Haines CJ, Leung TN, Poon PM, et al. Quantitative analysis of fetal DNA in maternal plasma and serum: implications for noninvasive prenatal diagnosis. Am J Hum Genet. 1998;62:768-75.

34. Li Y, Zimmermann B, Zhong XY, Gupta AK, Holzgreve W, Hahn $\mathrm{S}$. Determination of RhD zygosity using real-time guantitative PCR. Swiss Med Wkly. 2003;133:442-5.

35. Hyland CA, Gardener GJ, Davies H, Ahvenainen M, Flower RL, Irwin D, et al. Evaluation of non-invasive prenatal RHD genotyping of the fetus. Med J Aust. 2009;191:21-5.

36. Gahan P, Swaminathan R. Circulating nucleic acids in plasma and serum. Recent developments. Ann N Y Acad Sci. 2008 Aug;1137:1-6.

37. Steele CD, Wapner RJ, Smith JB, Haynes MK, Jackson LG. Prenatal diagnosis using fetal cells isolated from maternal peripheral blood: a review. Clin Obstet Gynecol. 1996;39 (4):801-13.

38. Stimson JL, Elias S. Isolating fetal cells in maternal circulation for prenatal diagnosis. Prenat Diagn. 1994;14:1229-42.

39. Bischoff FZ, Lewis DE, Nguyen DD, Murrell S, Schober W, Scott J, et al. Prenatal diagnosis with use of fetal cells isolated from maternal blood: five-color fluorescent in situ hybridization analysis on flow-sorted cells for chromosomes X, Y, 13, 18, and 21. J Reprod Med. 1997;42(4):193-9.

40. Bianchi DW, Zickwolf GK, Yih MC, Flint AF, Geifman OH, Erikson MS, et al. Erythroid-specific antibodies enhance detection of fetal nucleated erythrocytes in maternal blood. Prenat Diagn. 1993;13:293-300.

41. Lo YMD. Noninvasive prenatal detection of fetal chromosomal aneuploidies by maternal plasma nucleic acid analysis: a review of the current state of the art. BJOG. 2009;116:152-7.

42. Bustamante-Aragones A, Trujillo-Tiebas MJ, Gallego-Merlo J, de Alba MR, Gonzalez-Gonzalez C, Cantalapiedra D, et al. Prenatal diagnosis of Huntington disease in maternal plasma: direct and indirect study. Eur J Neurol. 2008;15:1338-44.

43. Bustamante-Aragones A, Gallego-Merlo J, Trujillo-Tiebas MJ, de Alba MR, Gonzalez-Gonzalez C, Glover G, et al. New 
strategy for the prenatal detection/exclusion of paternal cystic fibrosis mutations in maternal plasma. J Cyst Fibros. 2008;7:505-10.

44. Costa JM, Benachi A, Gautier E. New strategy for prenatal diagnosis of X-linked disorders [letter]. N Engl J Med. 2002;346:1502.

45. Lo YM, Leung TN, Tein MS, Sargent IL, Zhang J, Lau TK, et al. Quantitative abnormalities of fetal DNA in maternal serum in preeclampsia. Clin Chem. 1999;45:184-8.

46. Farina A, Shane ESL, Romero R, Gomez R, Chaiworapongsa T, Rizzo N, et al. High levels of fetal cell-free DNA in maternal serum: a risk factor for spontaneous preterm delivery. Am J Obstet Gynecol. 2005;193:421-5.

47. Sekizawa A, Jimbo M, Saito H, Iwasaki M, Sugito Y, Yukimoto $\mathrm{Y}$, et al. Increased cell-free fetal DNA in plasma of two women with invasive placenta. Clin Chem. 2002;48:353-4.

48. Hassold T, Abruzzo M, Adkins K, Griffin D, Merrill M, Millie E, et al. Human aneuploidy: incidence, origin, and etiology. Environ Mol Mutagen. 1996;28:167-75.

49. Epstein CJ. Down syndrome (trisomy 21). In: Scriver CR, Beaudet AL, Sly WS, Valle D, editors. The metabolic and molecular bases of inherited diseases. New York: McGraw-Hill; 2001. p. 1223-56.

50. Kusters MA, Verstegen RH, Gemen EF, de Vries E. Intrinsic defect of the immune system in children with Down syndrome: a review. Clin Exp Immunol. 2009;156(2):189-93.

51. Chang JH, Ho CS, Huang FY, Shyur SD, Lin DS, Lee HC. Clinical characteristics and survival of trisomy 18 in a medical center in Taipei, 1988-2004. Am J Med Genet A. 2006;140 (9):945-51.

52. Munne S, Sandilinas M, Magli C, Gianaroli L, Cohen J, Warburton D. Increased rate of aneuploid embryos in young women with previous aneuploid conceptions. Prenat Diagn. 2004;24:638-43.

53. Jones KL. Padrões Reconhecíveis de Malformações Congênitas. São aulo, SP, Brazil: Editora Manole Ltda; 1998.

54. Thornton FG, Onwude FL. Prenatal diagnosis. Prog Obstet Gynaecol. 1998;10:13-31.

55. Bubb JA, Matthews AL. What's new in prenatal screening and diagnosis? Prima Care. 2004;31:561-82.

56. Zournatzi V, Daniilidis A, Karidas C, Tantanasis T, Loufopoulos A, Tzafettas J. A prospective two years study of first trimester screening for Down syndrome. Hippokratia. 2008;12(1):28-32.

57. Krantz DA, Larsen JW, Buchanan PD, Macri JN. First-trimester Down syndrome screening: free beta-human chorionic gonadotropin and pregnancy-associated plasma protein A. Am J Obstet Gynecol. 1996;174:612-6.

58. Cicero S, Bindra R, Rembouskos G, Spencer K, Nicolaides KH. Integrated ultrasound and biochemical screening for trisomy 21 at 11 to 14 weeks. Prenat Diagn. 2003;23:306-10.

59. Nicolaides KH. Nuchal translucency and other first trimester sonographic markers of chromosomal abnormalities. Am J Obstet Gynecol. 2004;191:45-67.

60. Crossley JA, Aitken DA, Cameron AD, McBride E, Connor JM. Combined ultrasound and biochemical screening for Down Syndrome in the first trimester: a Scottish multicentre study. BJOG. 2002;106:667-76.

61. Ruiz C, Lamm F, Hart PS. Turner syndrome and multiple-marker screening. Clin Chem. 1999;45(12):2259-61.

62. Frías JL, Davenport ML, Committee on Genetics and Section on Endocrinology. Health supervision for children with Turner syndrome. Pediatrics. 2003;111(3):692-702.

63. Driscoll DA, Salvin J, Sellinger B, Budarf ML, McDonald-McGinn $\mathrm{DM}$, Zackai EH, et al. Pervalence of 22q11 microdeletions in DiGeorge and velocardiofacial syndromes: implications for genetic counseling and prenatal diagnosis. J Med Genet. 1993;30:813-7.

64. Driscoll DA, Budarf ML, Emanuel BS. Antenatal diagnosis of DiGeorge syndrome. Lancet. 1991;338:1390-1.

65. Conley ME, Bechwith JB, Mancer JFK, Tenckhoff L. The spectrum of the DiGeorge syndrome. J Pediatr. 1979;94:883-90.

66. Van Hemel JO, Schaap C, Van Opstal D, Mulder MP, Niermeijer MF, Meijers JHC. Recurrence of DiGeorge syndrome: prenatal detection by FISH of a molecular 22q11 deletion. J Med Genet. 1995;32:657-8.

67. Puder KS, Humes RA, Gold RL, Bawle EV, Goyert GL. The genetic implication for preceding generations of the prenatal diagnosis of interrupted aortic arch in association with unsuspected DiGeorge anomaly. Am J Obstet Gynecol. 1995;173:239-41.

68. Davidson A, Khandelwal M, Punnett HH. Prenatal diagnosis of the 22q11 deletion syndrome. Prenat Diagn. 1997;17:380-3.

69. Crawford DC, Acuna JM, Sherman SL. FMR1 and the fragile $x$ syndrome: Human genome epidemiology review. Genet Med. 2001;3:359-71.

70. Willemsen R, Los F, Mohkamsing S, van den Ouweland A, Deelen W, Galjaard H, et al. Rapid antibody test for prenatal diagnosis of fragile $\mathrm{X}$ syndrome on amniotic fluid cells: a new appraisal. J Med Genet. 1997;34(3):250-1.

71. Rousseau F, Heitz D, Biancalana V, Blumenfeld S, Kretz C, Boué J, et al. Direct diagnosis by DNA analysis of the fragile $\mathrm{X}$ syndrome of mental retardation. $\mathrm{N}$ Engl J Med. 1991;325:1673-81.

72. Oostra BA, Jacky PB, Brown WT, Rousseau F. Guidelines for the diagnosis of fragile X syndrome. J Med Genet. 1993;30:410 3.

73. Kerem B, Rommens JM, Buchanan JA, Markiewicz D, Cox TK, Chakravarti A, et al. Identification of the cystic fibrosis gene: genetic analysis. Science. 1989;245:1073-80.

74. Welsh MJ, Tsui L-C, Boat TF, Beaudet AL. Cystic fibrosis. In: Scriver CR, Beaudet AL, Sly WS, Valle D, editors. The metabolic and molecular bases of inherited disease. 7th ed. New York: McGraw-Hill; 1995. p. 3799-876.

75. Muller F, Dommergues M, Simon-Bouy B, Ferec C, Oury JF, Aubry MC, et al. Cystic fibrosis screening: a fetus with hyperechogenic bowel may be the index case. J Med Genet. 1998;35(8):657-60.

76. Cystic Fibrosis Genetic Analysis Consortium. Online cystic fibrosis mutation data. http://www.genet.sickkids.on.ca/cftr/.

77. Lerer I, Laufer-Cahana A, Rivlin JR, Augarten A, Abeliovich D. A large deletion mutation in the CFTR gene (312011 kbdel8.6 kb): a founder mutation in the Palestinian Arabs. Hum Mutat. 1999;13:337.

78. Dork T, Macek M Jr, Mekus F, Tummler B, Tzountzouris J, Casals $\mathrm{T}$, et al. Characterization of a novel $21-\mathrm{kb}$ deletion, CFTRdele2,3 (21 kb), in the CFTR gene: a cystic fibrosis mutation of Slavic origin common in Central and East Europe. Hum Genet. 2000;106:259-68.

79. Stromme P, Bjornstad PG, Ramstad K. Prevalence estimation of Williams syndrome. J Child Neurol. 2002;17:269-71.

80. Zaghloul N, Hutcheon RG, Tepperberg JH. Visual diagnosis: monozygotic twins who have congenital heart disease and distinctive facial features. Pediatr Rev. 2002;23(10):365-7.

81. Jones KL. Smith's Recognizable patterns of human malformation. Philadelphia: Saunders; 2006, 6th ed., p. 121.

82. Orioli IM, Castila EE, Barbosa-Neto JG. The birth prevalence rates for the skeletal dysplasias. J Med Genet. 1986;23:328-32.

83. Martínez-Frías ML, Cereijo A, Bermejo E, López M, Sánchez M, Golnalo C. Epidemiological aspects fo Mendelian syndromes in a Spanish population sample: I. autosomal dominant malformation syndromes. Am J Med Genet. 1991;38:622-5. 
84. Stoll C, Dott B, Roth MP, Alembik Y. Birth prevalence rates of skeletal dysplasias. Clin Genet. 1989;35:88-92.

85. Trujillo-Tiebas MJ, Fenollar-Cortés M, Lorda-Sánchez I, Díaz-Recasens J, Carrillo Redondo A, Ramos-Corrales C, et al. J Prenatal diagnosis of skeletal dysplasia due to FGFR3 gene mutations: a 9-year experience: prenatal diagnosis in FGFR3 gene. J Assist Reprod Genet. 2009;26:455-60.

86. Parrilla BV, Leeth EA, Kambich MP, Chilis P, MacGregor S. Antenatal detection of skeletal dysplasias. J Ultrasound Med. 2003;22:255-8.

87. Lim JH, Kim MJ, Kim SY, Kim HO, Song MJ, Kim MH, et al. Non-invasive prenatal detection of achondroplasia using circulating fetal DNA in maternal plasma. J Assist Reprod Genet. 2011;28(2):167-72.

88. Byers PH, Steiner RD. Osteogenesis imperfecta. Annu Rev Med. 1992;43:269-82.

89. Crncevic-Orlic Z, Raisz LG. Causes of secondary osteoporosis. J Clin Densitom. 1998;2(1):79-92.

90. Lynch JR, Ogilvie D, Priestley L, Baigrie C, Smith R, Farndon P, Sykes B. Prenatal diagnosis of osteogenesis imperfecta by identification of the concordant collagen 1 allele. J Med Genet. 1991;28:145-50.

91. Benn PA, Egan JFX, Fang M, Smith-Bindman R. Changes in the utilization of prenatal diagnosis. Obstet Gynecol. 2004;103:1255-60.

92. Bubb JA, Matthews AL. What's new in prenatal screening and diagnosis? Prim Care. 2004;31:561-82.
93. Elias S, Simpson JL, Bombard AT. Amniocentesis and fetal blood sampling. In: Milunsky A, editor. Genetic disorders and the fetus: diagnosis, prevention, and treatment. 4th ed. Baltimore: Johns Hopkins University Press; 1998. p. 53-82.

94. Jenn-Jhy T, Min-Min C, Feng-Chu L, Hui-Yu L, Min-Hui C, Shih-Chu HE. Detection of chromosome aberrations in the second trimester using genetic amniocentesis: experience during 1995-2004. Taiwan J Obstet Gynecol. 2006;45 (1):39-41.

95. Robinson A, Linden M. Clinical genetics handbook. Massachusetts: Blackwell; 1993. p. 614.

96. http://apps.who.int/gb/ebwha/pdf_files/EB116/B116_3-en.pdf

97. Akbayram S, Sari N, Akgün C, Doğan M, Tuncer O, Caksen H, et al. The frequency of consanguineous marriage in eastern Turkey. Genet Couns. 2009;20(3):207-14.

98. Tunçbilek E. Clinical outcomes of consanguineous marriages in Turkey. Turk J Pediatr. 2001;43(4):277-9.

99. Kantarcı S, Eraslan S, Laleli KY. Türk toplumunda sık görülen kalıtsal hastalıklarda PCR tekniğine dayalı DNA tanı yöntemlerinin geliştirilmesi ve servis olarak sunulması. Perinatoloji Dergisi. 1999;7(1):15-22.

100. http://www.geneticalliance.org.uk/education3.htm.

101. http://www.saglik.gov.tr/ACSAB/belge/1-747/ana-cocuk-sagligive-aile-planlamasi-genel-mudurlugunun-.html?vurgu=genetik.

102. http://www.saglik.gov.tr/ACSAB/belge/1-11538/2008-bebekolumleri-arastirmasi-ve-bilimsel-calisma-gru-.html. 